\title{
Emotional Labour in University Lecturers: Considerations for Higher Education Institutions
}

\author{
Karen Berry ${ }^{1}$ \& Simon Cassidy ${ }^{1, *}$ \\ ${ }^{1}$ School of Health Sciences, University of Salford, UK \\ *Corresponding author: School of Health Sciences, University of Salford, UK. E-mail: S.Cassidy@salford.ac.uk
}

Received: May 24, 2013

Accepted: June 28, $2013 \quad$ Online Published: July 30, 2013

doi:10.5430/jct.v2n2p22

URL: http://dx.doi.org/10.5430/jct.v2n2p22

\begin{abstract}
Emotional labour is a state that exists when there is a discrepancy between the emotional demeanour that an individual displays and the genuinely felt emotions that would be inappropriate to display (Mann 1999b).The study examined levels of emotional labour in university lecturers and compared these data to other occupations. Employing a mixed methods design, a sample of 61 university lecturers participated in the study. Emotional labour was measured using Mann's Emotional Requirements Inventory (MERI). Results showed that university lecturers reported significantly higher levels of emotional labour than other occupations including mental health nurses and a mix of frontline and back office employees. Age and length of service were found to be significant factors for emotional labour in university lecturers. Qualitative findings identified the main themes as increased workloads, eroding job autonomy, uncertainty about the future and job satisfaction. Based on findings from the study, a conceptual model of emotional labour in higher education was proposed, the Higher Education Emotional Labour Model (HEEL). Implications for university senior management in recognising the high levels of emotional labour levels were considered. Further suggested research directions considered include work to determine the frequency of emotional labour in university lecturers, testing the validity of the proposed Higher Education Emotional Labour Model and investigating the job role characteristics of a university lecturer.
\end{abstract}

Keywords: emotional labour; university lecturers; change in higher education

\section{Introduction}

\subsection{Background}

There continue to be on-going changes and developments within higher education in the United Kingdom. One major development has been extensive and continual shifts towards greater efficiencies and a more managerial approach to control and standardisation in order to meet the challenges of implementing major government initiatives to raise and widen higher education participation for 18 to 30 year olds to 50\% (DfES, 2005) against significant reductions in public funding. These continual changes are directly increasing the job-specific role demands now being placed on university lecturers (Ogbonna \& Harris, 2004). Ogbonna and Harris (2004) have noted that unlike other professions, university lecturers are also subjected to multiple and sometimes conflicting demands. Reports (Asthana, 2008; UCU, 2008a) have also highlighted how university lecturers are struggling to cope with the practicalities of rising student numbers and increased administration duties. Moreover, Kinman (2008) has also reported a recent rise in stress levels within UK universities claiming that it is due to a number of factors including rising student numbers; diversification of modes of delivery; restructuring and mergers resulting in high job insecurity; increased demands for efficiency and accountability; increased commercialisation; reductions in funding; and the move towards financial self-reliance for institutions. The University and College Union in the UK (2008b) also presented a damning report on UK universities which revealed that levels of stress in higher education are now considerably worse than Health and Safety Executive (HSE) recommendations, which are the standards of psychosocial working conditions set out by the Health and Safety Executive (2008).

Since the rise in tuition fees between 2006 and 2012, UK higher education can be viewed as a commodity (Naidoo, 2008) and it is increasingly being recognised that the 'inherent characteristics of other service-related industries' are now being adopted in higher education (Constanti \& Gibbs, 2004). Universities are increasingly being considered 
service institutions and their students perceived as customers (Constanti \& Gibbs, 2004). University lecturers are faced with satisfying the increasing demands of paying students whilst at the same time adhering to the increasingly prescriptive academic standards and reduced autonomy (Constanti \& Gibbs, 2004). Kinman and Jones (2004) report that front-line service delivery, that is teaching and assessment, is now becoming more of a psychological strain.

\subsection{Emotional Labour}

The general growth of UK services and the 'culture of the customer' have led to a greater emphasis on the management of employees' emotional displays as a source of competitive advantage (Sturdy, 1998) with the guiding principles being productivity, quality and profit (Lewis \& Simpson, 2007). The expression and display of workplace desired emotional expectations during any interpersonal transactions requires emotional effort by employees (Morris \& Feldman, 1996). Furthermore, the faking or suppression of an emotional display, because of the demands of a job, is now a widely accepted condition of any role that involves interacting and working with people (Mann, 1999a). This act of faking, suppressing or displaying emotions to create an impression as part of a job was first defined by Hochschild (1983) as emotional labour. Emotional labour is a state that exists when there is a discrepancy between the emotional demeanour that an individual displays and the genuinely felt emotions that would be inappropriate to display (Mann, 1999b). Mann (1999a) also found that this state can be relevant to two-thirds of all workplace interactions and it means that in order for work standards to be maintained and job targets achieved, employees not only have to consider the job in hand, but also how they perform it.

There is a strong argument that university lecturers perform emotional labour and that levels are increasing (Constanti \& Gibbs 2004; Ogbonna and Harris 2004). Lecturing requires varying degrees of emotional displays over extended periods with the demand to show or exaggerate some emotions (Ogbonna \& Harris, 2004) and to minimise or suppress the expression of other emotions (Ybema \& Smulders, 2002). As well as undertaking lecturing, university lecturers also carry out a wide range of disparate tasks including research, administration, management and student counselling (Ogbonna \& Harris, 2004). Research carried out by Ogbonna and Harris (2004) found that there is widespread discontent and dissatisfaction within the university lecturer community which, they reported, was being masked by increased emotional labour deployed to enable lecturers to meet changing occupational and organisational expectations. In their study, Ogbonna and Harris (2004) regarded emotional labour as a 'coping mechanism' because university lecturers were dissatisfied with the reduction in autonomy and increased management control. In addition to this, Constanti and Gibbs (2004) found that university lecturers were being exploited in a three-way relationship involving customers (students), the demands of their job role and senior management pressures. Conceptualising academic institutions as service providers, Constanti and Gibbs (2004) also concluded that university lecturers are expected to perform high levels of emotional labour in order to achieve the dual outcomes of student satisfaction and increased institutional profit demanded by university senior management.

Emotional labour can foster both satisfaction and dissatisfaction for employees (Sharma \& Black, 2001). As a result, emotional labour has often been described as a double-edged sword (Ashforth \& Humphrey, 1993) being both functional for the organisation and dysfunctional for the employee. Emotional labour has long been associated with stress in the workplace. Employees in service related roles or occupations falling within categories of high emotional labour such as nursing, air-hostessing, a range of hospital job roles and counsellors (Hochschild, 1983) were all found to report significantly higher levels of stress. Wharton (1993) also argued that job demands unique to occupations involving emotional labour can be viewed as a specific source of job-related stress. This is because the frequent requirement to express or display an emotion that is not felt, or which is incompatible with experienced emotions, can be potentially damaging to employee well-being (Hochschild, 1983; Mann, 1999a).

That Hochschild (1983) has described the consequences of emotional labour as harmful has, in turn, led to the assumption that emotional labour is inevitably experienced this way. In support of such an assumption, a number of dissatisfaction factors have been associated with emotional labour that appear mainly to be due to the dissonance between self and true feelings (Hochschild 1983). These include, for example, feeling robotic, un-empathetic (Albrecht \& Zembe, 1985), role overload and burnout (Wharton \& Erickson, 1993). Maslach and Jackson (1981) also argued that burnout is a syndrome related to emotional exhaustion and cynicism, which occurs frequently among employees who have high people contact, and are strongly associated with deterioration in service quality, high job turnover, absenteeism and low morale (Brotheridge \& Gandey, 2002; Maslach \& Jackson, 1981). Furthermore, Welch (1997) argued that experiencing high levels of emotional labour can amount to workplace 'emotion exploitation' and can cause depression, alienation, exhaustion and loss of identity. Some authors do however report an alternative, positive view of the performance of emotional labour. In considering professions that require 'high people contact' such as teaching, Hargreaves (2000) reported that performing emotional labour can be 
pleasurable, rewarding, and that often teachers largely enjoy the emotional labour of working with students because this helps them meets their core classroom purposes. Shuler and Sypher (2000) also argued that when emotional labour is conducted for the benefit of students, or for a teacher's own reward and satisfaction, rather than because of organisational demand display rules, then job satisfaction can actually increase.

\subsection{The Present Study}

Few studies have explored how university lecturers are seeking to cope with the wide-ranging changes and developments in their labour processes and the diverse nature of and frequently conflicting demands now being imposed by higher education institutions (Constanti \& Gibbs, 2004) and, most importantly in the context of this particular study, how this is impacting on emotional labour levels. Warranting further investigation then, this study examines emotional labour in a sample of university lecturers in order to achieve several objectives and aims. Firstly, to establish current levels of emotional labour in university lectures and compare these with published norms emanating from two emotional labour studies undertaken with a diverse range of occupational job roles by Mann (1999a) and Mann and Cowburn (2005). In the light of existing research and recent and ongoing change and development in higher education, it is anticipated that university lecturers will report higher levels of emotional labour compared to published norms. To investigate any difference in levels of emotional labour reported by male and female university lecturers. Secondly, to examine sample demographics as significant factors for emotional labour in university lecturers; gender, age, length of service and hours of employment (full-time / part-time) are included as relevant factors (e.g. Erickson \& Ritter, 2001). Finally, to explore, using a qualitative approach, how much job autonomy university lecturers feel they have, what the key job stressors are (if any) and how satisfied or dissatisfied they are in their current roles. A further aim is to propose a conceptual model of emotional labour in context of higher education.

In addressing each of these objectives, emotional labour is operationalised, in line with previous studies, as: the internal effort or suppression of hidden emotions and also the external effort or the faking of emotions not felt and the emotional display (Mann 1999a).

\section{Methodology}

\subsection{Design}

This was a questionnaire-based survey using a mixed methodological approach. Quantitative and qualitative data were collected using Mann’s Emotional Requirements Inventory (MERI) scale for emotional labour. Age, gender, length of service and hours of employment were also recorded in order to provide grouping variables enabling between groups comparative analysis of emotional labour levels.

\subsection{Participants}

61 university lecturers from across faculty schools within a UK university participated in the study (full-time n=47 and part-time $n=14$ ). This represented a response rate of 23 per cent. The demographics of the sample of university lecturers are presented in Table 1.

Table 1: Sample Demographics

\begin{tabular}{llll}
\hline Demographic Variables & Range & Mean & SD \\
\hline Age $\mathrm{n}=61$ & 29-56 years & 42.92 years & 8.3 \\
Age [Males] $\mathrm{n}=24$ & 30-56 years & 45.16 years & 8.2 \\
Age [Females] $\mathrm{n}=37$ & 29-56 years & 41.45 years & 8.1 \\
Length of Service (LOS) & 6 months - 33 years & 6.92 years & 5.7 \\
LOS [Males] $\mathrm{n}=24$ & 2-33 years & 9.5 years & 8.9 \\
LOS [Females] $\mathrm{n}=37$ & 2-17 years & 6.11 years & 3.7 \\
\hline
\end{tabular}

\subsection{Published Norms}

Published norms data originate from two emotional labour studies, Mann and Cowburn (2005) and Mann (1999a) and resulting data are summarised in Mann (1999b, p. 122-130). Mann's published norms data are based on a sample of 172 participants from a range of job roles. A feature of Mann's studies was for the 172 employee participants to complete up to 5 inventories, using varied face-to-face communication interactions, this resulted in 675 emotional 
labour inventories (MERIs) being completed. Thus, an average total score was calculated for each of the 172 employee participants. In the present study, each participant only completed one emotional labour inventory (MERI) based on one chosen face-to- face communication interaction with either students or colleagues (e.g. supervision meeting, staff meeting).

The 172 participants included in Mann's published norms data were employees were from across 12 UK companies with a mix of front-line employees $(n=90)$ and back office employees $(n=47)$ who participated in the Mann (1999a) study and 35 mental health nurses from three UK psychiatric hospitals who participated in the Mann and Cowburn (2005) study. No demographic data are available for the 172 participants represented in the published norms.

\subsection{Measures}

To determine levels of emotional labour Mann’s Emotional Requirements Inventory (MERI) scale (Mann, 1999a; 1999b) was used. The inventory has 17 statement items that can be further categorised into three emotional labour sub-scales emotional display, the degree to which participants expressed genuine felt emotions during an interaction; emotional suppression, the degree to which participants reported to have hidden emotions during the interaction and emotional faking, the degree to which participants expressed emotions that they did not actually feel but that were appropriate to express at the time (Mann, 2005). Responses to each statement item were measured on an eight-point Likert Scale ranging from 1 = "A Lot" to 8 = "Not at All". A lower MERI score indicated higher levels of emotional labour. The range of potential scores on the MERI were categorised by Mann to provide indicative levels of emotional labour across the range 'very high' to 'low' (see Table 2).

Table 2: Emotional Labour Scoring Bands (Mann, 1999b)

\begin{tabular}{lllll}
\hline \multicolumn{5}{l}{ EMOTIONAL LABOUR SCORING BANDS (17-136) } \\
\hline \multirow{4}{*}{ *MERI Total } & Very High & High & Moderate & Low \\
& $17-47$ & $48-77$ & $78-107$ & $108-136$ \\
\hline
\end{tabular}

\section{*Lower MERI total indicates higher levels of emotional labour}

In order to fulfil a mixed-methodological approach, qualitative data, in addition to quantitative MERI data, were gathered using three open-ended questions using the prompts (1) How much autonomy do you feel you have in your current role? - has it recently changed? - do you feel in control? - do you feel involved in decision making? (2) What do you think are the current key stressors in your role (if any)? - how do you see the future? (3) How satisfied or dissatisfied are you in your current role? - has it recently changed? - how do you perceive the future? According to Greene (1997) a mixed-method approach can be advantageous because it enables a test of consistency of findings across data sources allowing the ability to challenge findings from one method with those from another. It also enables findings from one method to be further clarified or illustrated by findings from a complimentary method, adding richness and detail, deepening understanding of findings; and providing new directions or research questions. Mixed-method approaches that combine traditional quantitative approaches to measurement with qualitative approaches can exploit the strengths of each approach, overcoming the limitations of a single method approach (Spratt, Walker, \& Robinson, 2004).

\subsection{Procedure}

Following receipt of confirmation from each of the seven faculty heads of school, 269 randomly selected university lecturers were contacted by email requesting their participation. Following agreement to participate, participants were directed to an online platform for delivery of the customised Mann's MERI survey tool. Following MERI completion the resulting data were anonymously and automatically saved into an online data collection site in preparation for data analysis.

\subsection{Quantitative Data Analysis}

Mann's published norms data were presented as an overall mean total MERI score for the sample of 172 participants and a mean total MERI score for each item ( $\mathrm{n}=17$ ) (see summary scores in Mann 1999b, p. 122-130). In order that between groups comparative analysis could be conducted, a mean MERI total score and mean total MERI score for each item were also calculated for the sample of university lecturers $(n=61)$ (see Table 4b). One sample and independent sample t-tests compared between group differences (university lecturers and published norms) in total and sub-scale (display, suppression and faking) MERI scores.

\subsection{Qualitative Data Analysis}

The qualitative feedback [data corpus], for the sample of university lecturers, from the three additional questions (1) 
How much autonomy university lecturers feel they have in their roles currently, (2) What the current role key stressors (if any) and (3) How satisfied or dissatisfied they are in their current roles, were analysed thematically using Braun and Clarke (2005) data analysis process (see Table 3). The themes were identified within the explicit or surface meanings of the data and the researchers did not look for anything beyond what the sample population of university lecturers had written.

Table 3: Phases of Thematic Analysis (Braun \& Clarke, 2005)

PHASE DESCRIPTION OF THE PROCESS

$\begin{array}{ll}\begin{array}{l}\text { 1. Data familiarization: } \\ \text { 2. Generating initial codes: }\end{array} & \begin{array}{l}\text { Reading and re-reading the data, noting down initial ideas. } \\ \text { Coding interesting features of the data in a systematic fashion across the entire data } \\ \text { set, collating data relevant to each code. }\end{array} \\ \begin{array}{l}\text { 3. Searching for themes: } \\ \text { Collating codes into potential themes, gathering all data relevant to each potential } \\ \text { theme. } \\ \text { Checking if the themes work in relation to the coded extracts (Level 1) and the entire } \\ \text { data set (Level 2), generating a thematic 'map' of the analysis. }\end{array} \\ \begin{array}{l}\text { 4. Reviewing themes: } \\ \text { Ongoing analysis to refine the specifics of each theme, and the overall story the } \\ \text { analysis tells, generating clear definitions and names for each theme. } \\ \text { themes: }\end{array} \\ \begin{array}{l}\text { The final opportunity for analysis. Selection of vivid, compelling extract examples, } \\ \text { final analysis of selected extracts, relating back of the analysis to the research } \\ \text { question and literature, producing a scholarly report of the analysis. }\end{array}\end{array}$

\section{Results}

\subsection{Quantitative Results}

Table 4b: MERI Statement Item and Sub-scale Mean Scores for University Lecturers and Published Norms

\begin{tabular}{|c|c|c|c|}
\hline & MERI Statement Item & $\begin{array}{l}\text { *University } \\
\text { Lecturers } \\
\text { Mean score } \\
\text { per item }\end{array}$ & $\begin{array}{l}\text { *Published } \\
\text { Norma data } \\
\text { Mean score } \\
\text { per item }\end{array}$ \\
\hline 1 & $\begin{array}{l}\text { How much during the encounter did you hide (or try to hide) some kind } \\
\text { of emotion from the other person? }\end{array}$ & 3.6 & 5.9 \\
\hline 2 & $\begin{array}{l}\text { Because of events in my personal life or at work, I felt negative (e.g. } \\
\text { depressed, upset, angry, frustrated) BEFORE this encounter, but felt that } \\
\text { I had to try to hide my feelings and put on a 'brave' face to the other } \\
\text { person(s). }\end{array}$ & 4.5 & 6.7 \\
\hline 3 & $\begin{array}{l}\text { Because of events in my personal life or at work, I felt positive (e.g. } \\
\text { excited, happy, proud) BEFORE this encounter, but felt that I had to try } \\
\text { to hide (or tone down) my feelings from the other person. }\end{array}$ & 5.2 & 6.9 \\
\hline 4 & $\begin{array}{l}\text { During the encounter, I felt that I was 'acting' a role or taking on a role } \\
\text { such as helper, advisor, expert, teacher, parent, counsellor or boss. }\end{array}$ & 3.4 & 4.7 \\
\hline 5 & $\begin{array}{l}\text { At some point during the encounter I felt that I intentionally conveyed (or } \\
\text { attempted to convey) a positive emotion or feeling that I did not really } \\
\text { feel but that was appropriate at the time (I pretended to be happy, excited, } \\
\text { interested). }\end{array}$ & 3.1 & 5.5 \\
\hline 6 & $\begin{array}{l}\text { At some point in the encounter, I intentionally conveyed (or attempted to } \\
\text { convey) a negative emotion or feeling that I did not really feel but that } \\
\text { was appropriate at the time (I pretended to be angry, upset, dismayed } \\
\text { etc.). }\end{array}$ & 5.2 & 7 \\
\hline 7 & $\begin{array}{l}\text { During the encounter, I felt that the other person(s) expected me to take } \\
\text { on a role such as helper, advisor expert. }\end{array}$ & 2.7 & 4.2 \\
\hline
\end{tabular}


8 I felt that I acted differently in this encounter than I would have done at home with friends.

9 I felt a bit 'fake' as if I was not really being 'me' at some point in this 3.9 encounter.

10 I felt that I suppressed or hid (or tried to) positive emotions at some point 4.6 in this encounter (e.g. I felt happy or excited but tried not to show it).

11 I felt that I suppressed or hid (or tried to) negative emotions at some point in this encounter (e.g. I felt angry, depressed or dismayed but I tried not to show it).

12 I felt that at some point, the other person expected me to have a particular 'face' or disposition (e.g. they expected me to act friendly, helpful, enthusiastic, cool, emotionless, distant, warm etc.).

13 I 'psyched' myself up so that I would genuinely feel any emotion that I was expected to feel (e.g. the other person(s) was very excited so I tried to work up enthusiasm too.

14 At some point, I laughed or frowned because it was expected, rather than because I found something amusing or distressing.

15 At some point I felt stressed or found it a strain because I could not show 3.9 my true feelings (because it would not have been appropriate).

16 At some point during the encounter I felt stressed or found it a strain 3.6 because it was difficult to maintain the role that I was taking on.

17 I felt that there were rules or protocol about how I spoke or acted in this 1.5 encounter (e.g. my employers expect people in my position to behave in a certain way or have certain manner).

$\begin{array}{lll}\text { *Mean MERI total score } & 62.3 & 97.7 \\ \text { *Mean MERI item score } & 3.62 & 5.74 \\ & \text { (SD 0.63) } & \text { (SD 0.75) }\end{array}$

*Lower MERI scores indicate higher levels of emotional labour

Mean total MERI score was 62.3 which indicated 'high' levels of emotional labour and published norms mean total MERI score was 97.7 which indicated only 'moderate' levels of emotional labour (see Table 2). A one sample t-test confirmed that university lecturers reported significantly higher emotional labour compared to Mann's published norms $(t(60)=11.696, p<0.05)$. Cohen's $d=3.02$, indicating a large effect size (Cohen, 1988). An independent t-test comparing MERI item scores $(n=17)$ across lecturer and published norm groups provided further evidence of significant differences between reported emotional labour levels $(t(32)=6.23, p<0.05)$. Cohen’s $d=3.06$, again indicating a large effect size (Cohen, 1988).

Table 5: Total MERI Scores Categorised by Scoring Band

\begin{tabular}{|c|c|c|c|c|c|}
\hline & & Emotional L & r Scoring ran & -136 & \\
\hline & $\mathrm{N}$ & $\begin{array}{l}\text { Score 17-47 } \\
\text { 'very high' }\end{array}$ & $\begin{array}{c}\text { Score } 48-77 \\
\text { 'high' }\end{array}$ & $\begin{array}{l}\text { Score } 78-107 \\
\text { 'moderate' }\end{array}$ & $\begin{array}{l}\text { Score } 108-136 \\
\text { 'low' }\end{array}$ \\
\hline University Lecturers & 61 & $28 \%(17)$ & $44 \%(27)$ & $24 \%(15)$ & $4 \%(2)$ \\
\hline Published norms & 172 & $5 \%(8)$ & $18 \%(31)$ & $59 \%(102)$ & $18 \%(31)$ \\
\hline *Published norms data by & ccul & & & & \\
\hline $\begin{array}{l}\text { *Front and Back Office } \\
\text { Workers }\end{array}$ & 137 & $8(6 \%)$ & $26(19 \%)$ & 78 (57\%) & $25(18 \%)$ \\
\hline *Mental Health Nurses & 35 & $0 \%$ & $5(15 \%)$ & 24 (67\%) & $6(18 \%)$ \\
\hline
\end{tabular}


The distribution of emotional labour scores (Table 5) shows that $28 \%$ of university lecturers scored in the 'very high' and $44 \%$ in the 'high' emotional labour scoring band range compared to only $5 \%$ and $18 \%$ respectively of workers represented in the published.

Table 6: Mean MERI Sub-scale Scores for University Lecturers and Published Norms

\begin{tabular}{lllll}
\hline Sub-scale & \multicolumn{2}{l}{$\begin{array}{l}\text { University Lecturers } \\
(\mathrm{n}=61)\end{array}$} & $\begin{array}{l}\text { Published norms } \\
(\mathrm{n}=172)\end{array}$ \\
\cline { 2 - 5 } & *Mean & SD & *Mean & SD \\
\hline Display & 2.98 & 0.84 & 4.93 & 1.22 \\
Suppression & 4.20 & 0.68 & 6.40 & 0.53 \\
Faking & 3.84 & 0.81 & 5.94 & 0.89 \\
Total & 3.62 & 0.63 & 5.74 & 0.75 \\
\hline
\end{tabular}

*Lower MERI scores indicate higher levels of emotional labour

Mean sub-scale scores reported by university lecturers for emotional display, suppression and faking were all lower than published norms sub-scale mean scores (Table 6) indicating higher emotional labour levels. One-sample t-tests confirmed significant differences between university lecturers and published norms for all three sub-scales: emotional display $(t(60)=17.342, p<0.05)$, emotional suppression $(t(60)=17.852, p<0.05)$ and emotional faking $(t(60)=15.817, p<0.05)$. Cohen's $d$ indicated large effect sizes for all three sub-scales: display $d=1.86$, suppression $d$ $=3.61$ and faking $d=2.47$ (Cohen, 1988).

Table 7: Mean MERI Total Scores for Male and Female University Lecturers

\begin{tabular}{llll}
\hline Gender & N & Mean Score & SD \\
\hline Male lecturers & 24 & 69.71 & 24.06 \\
Female lecturers & 37 & 57.78 & 22.30
\end{tabular}

\section{*Lower MERI scores indicate higher levels of emotional labour}

Although female lecturers reported higher mean emotional labour levels ( $d=0.51$, indicating a medium effect size) the difference was not significant $(t(59)=1.977, p>0.05)$.

Table 8: Mean MERI Scores for Full-time and Part-time University Lecturers

\begin{tabular}{llll}
\hline Employment type & $\mathrm{N}$ & ${ }^{*}$ Mean score & SD \\
\hline Full-time lecturers & 47 & 62.02 & 24.19 \\
Part-time lecturers & 14 & 64.00 & 22.09 \\
\hline
\end{tabular}

*Lower MERI scores indicate higher levels of emotional labour

Although full-time lecturers reported marginally higher emotional labour levels ( $d=0.09$ ), the difference in total emotional labour level scores between full-time and part-time university lecturers were not significant $(t(59)=.274$, $p>0.05)$.

Both age $(r(61)=.282, p<0.05)$ and length of service $(r(61)=.413, p<0.05)$ showed significant positive correlations with MERI total emotional labour scores, suggesting that emotional labour levels fall with increased age and length of service (see Figures 1 and 2), 


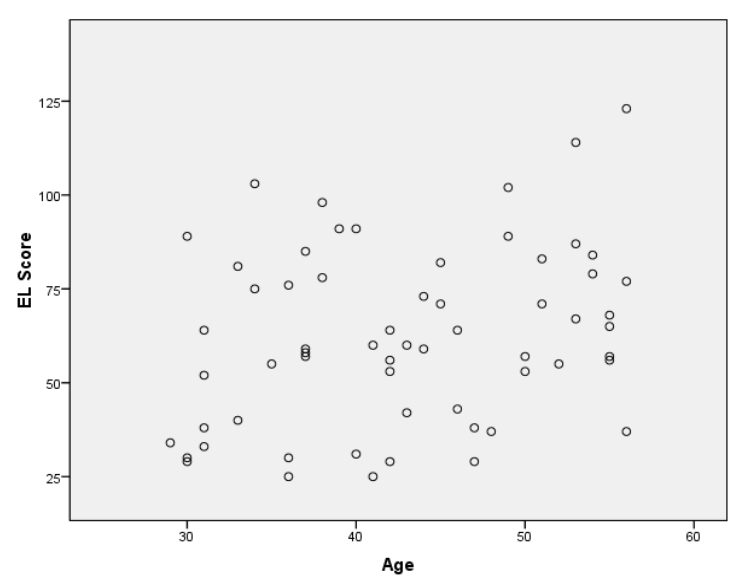

Figure 1: University Lecturers Age and MERI Scores

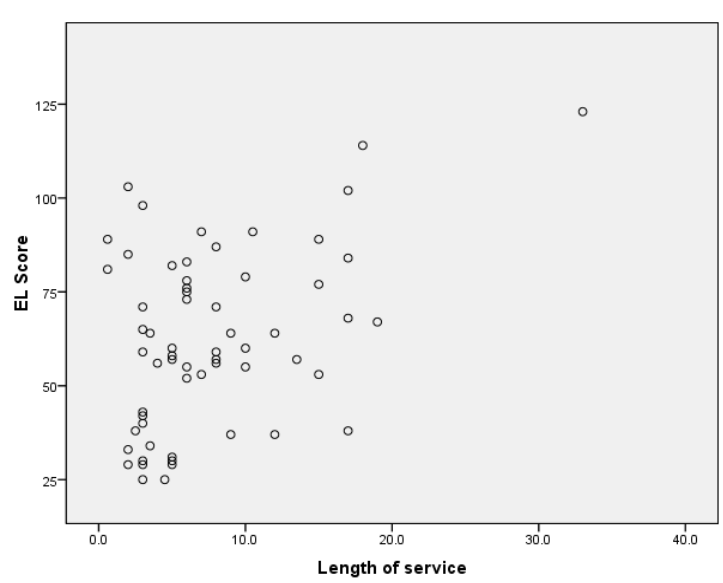

Figure 2: University Lecturers Length of Service and

\section{MERI Scores}

\subsection{Qualitative Results}

Tables 9, 10, and 11 show main themes identified with supporting data extracts in line with Braun and Clarke's (2005) process of thematic analysis.

Table 9: Job Autonomy

\begin{tabular}{ll}
\hline Main theme identified & Supporting Data Extract \\
\hline Have job autonomy but it is "Some autonomy but gets less almost each week. Everything seems to have \\
eroding \\
to be standardised which reduces autonomy and creativity Do not always \\
feel in control. Do not feel involved in decision making at all” (Respondent \\
$11)$ \\
"Some autonomy but I can see it is getting less and less..." (42) \\
"The autonomy in my role is okay but I can see that it is slowly eroding \\
away. If I compare to when I first started in my role it has got less". (25)
\end{tabular}

Question: How much autonomy do you feel you have in your current role? Has it recently changed? Do you feel in control? Do you feel involved in decision making?

Table 9 presents evidence indicating that this sample of university lecturers feel that they do currently have job autonomy but that it is eroding, which supports previous research findings (Constanti \& Gibbs 2004; Ogbonna \& Harris 2004; Naidoo 2008, Court 1999; Ritzer 1996; Willmott 1995). Relevant here is the work of Stenross and Kleinman (1989) who found that low control in the workplace can be associated to high emotional labour, which could explain high levels of emotional labour reported by university lecturers (see Table 4).

Table 10: Job Stressors

\begin{tabular}{|c|c|}
\hline Main theme identified & Supporting Data Extract \\
\hline \multirow[t]{3}{*}{ Increased workloads } & "Workloads and more and more students - doing more with less" (25) \\
\hline & "Workloads - increased pressures (admin) and feeling uncertain about the future" (44) \\
\hline & $\begin{array}{l}\text { "Obviously the threat of redundancy! Also workload is ridiculous sometimes - often in } \\
\text { fact - but right now, whilst engaged in heavy marking for the last three weeks, I am } \\
\text { working } 12 \text { hour days AND weekends. It's outrageous..." (15) }\end{array}$ \\
\hline \multirow[t]{2}{*}{ Uncertainty about the future } & “Job insecurity is a main element of stress” (29) \\
\hline & $\begin{array}{l}\text { "Current organisational changes and plans for further changes... There is a degree of } \\
\text { uncertainty linked to these issues. Increased workload and possible future increases as } \\
\text { a consequence of the above... Increase in administrative work related to my role as a } \\
\text { lecturer. The behaviour of some of the students... Unrealistic expectations placed upon } \\
\text { you from certain members of the team" (12). }\end{array}$ \\
\hline
\end{tabular}


Question: What do you think are the current key stressors in your role (if any)? How do you see the future?

Table 10 presents the two main themes of increased workloads and uncertainty about the future that were identified when university lecturers were questioned on the issue of perceived stressors. The identified themes fit with the findings of Kinman (2008) who reported a high increase in workload demands on university lecturers and also Ogbonna and Harris (2004) who found that increasing workloads could be being masked by high levels of emotional labour.

Table 11: Job Satisfaction

Main theme identified
$\begin{aligned} & \text { Satisfied in job and uncertain } \\ & \text { about the future }\end{aligned}$
the change in structure across the whole of the university and in my school
particularly. The future is uncertain, however I do experience a great deal of
job satisfaction and I see many of the changes as a challenge and that we need
to be working 'smarter' not 'harder'. We all need to work in partnership when
dealing with the processes and communication is the key issue here" (12)
"Still satisfied but worried about the future" (20)
"I love teaching and research, but the emphasis on cost-cutting and constant
pressure to dumb down makes me depressed about the future. The loss of
collegiality and the ability to influence the workplace with reasoned argument
as a managerialist control structure has been rapidly and brutally imposed has
made it difficult to achieve the level of superior performance that I pride myself
on.............." (52)
"I enjoy my job - if I was allowed to get on with what I am good at" (1)

Question: How satisfied or dissatisfied are you in your current role? Has it recently changed? How do you perceive the future?

Table 11 presents evidence for job satisfaction as a main theme related to the role and future role of a university lecturer. There appears to be some conflict with the other identified main themes of increased workloads, eroding job autonomy and uncertainty about the future (see Tables 9 and 10). Furthermore, high emotional labour levels (see Table 4) are usually associated with job dissatisfaction (Ashworth \& Humphrey, 1993; Hochschild 1983). A possible explanation for these-apparently — contradictory findings is that the sample of university lecturers did in fact report that they felt that they still had some job autonomy (see Table 9) and Shuler and Sypher (2000) did find that having job autonomy and control can be associated with job satisfaction.

\section{Discussion}

One of the major aims of the study was to establish current levels of emotional labour in a sample of university lecturers. The findings revealed that the sample of university lecturers performed 'high' levels of emotional labour according to Mann's (1999b) emotional labour level categories (see Table 2). High emotional labour levels support Constanti and Gibbs (2004) who found that increased emotional labour was masking widespread discontent and dissatisfaction within the university lecturer community, but enabling them to meet changing occupational and organisational expectations. Furthermore, the high levels of emotional labour found in this study also support Ogbonna and Harris (2004) who also found that emotional labour was being used as a coping mechanism as university lecturers were dissatisfied with the reduction in job autonomy and increased management control. In addition, the high levels of emotional labour found also support Mann (1997) and Mann (1999a) who found that high employee emotional labour levels are not just restricted to front-line, service-related industries or the caring professions, as argued by Hochschild (1983), but that it is prevalent within other workplace occupations.

Emotional labour levels reported by university lecturers were compared to published norms gathered from a sample of mixed occupational roles including 137 front-line and back-office employees from twelve 12 UK companies and 35 mental health nurses from three psychiatric hospitals (Mann 1999a; Mann \& Cowburn, 2005). Findings showed that university lecturers reported significantly higher levels of emotional labour compared to those occupations represented in the published norms. This is particularly revealing when it is considered that nursing is perhaps one of the occupations most commonly associated with extensive emotional work (Bolton, 2001) and a highly stressful 
work environment (Humpel \& Caputi, 2001). The distribution of emotional labour scores for university lecturers indicated that university lecturers most frequently reported 'high' levels of emotional labour compared to 'moderate' levels most frequently reported by other occupations.

Significant differences were also found between university lecturers and other occupations in both average emotional labour levels and in all three emotional labour sub-scale components; emotional display, suppression and faking, with university lecturers consistently reporting higher emotional labour levels.

Both age and length of service were related to emotional labour levels, with younger lecturers showing higher levels of emotional labour and shorter length of service associated with higher reported emotional labour. This suggested that longer serving or more experienced university lecturers perform lower levels of emotional labour compared to less experienced university lecturers. Previous research with nurses (Erickson \& Grove, 2008) also found that younger and less experienced nursing employees experienced higher levels of emotional labour compared to more experienced and older nursing employees. Low levels of emotional labour could also be an indicator for 'emotional deviance' (Mann 1999a; Lashley 2002) whereby an employee is displaying emotions that they genuinely feel despite organisational display rules (Lashley 2002), with this being more likely response form more experienced and high status employees who may be more secure or confident in their role. In contrast, less experienced employees may perform high levels of impression management (Goffman, 1959) whereby, through their inexperience in the role and immaturity, they may be trying to control the impressions that other people form of them (Mann 1999b). This would support the suggestion that less experienced university lecturers, through impression management, are performing even higher levels of emotional labour.

Whilst reported differences in levels of emotional labour between male and female university lecturers was not significant, the difference was approaching significance and a medium effect size was reported, with females reporting higher levels of emotional labour than males (see Table 7). Previous research (Meier, Mastracci \& Wilson 2006; Pierce, 1995) has found that display rules in organisations, that is the organisational expectations regarding the kind of emotions employees ought to express and suppress during interpersonal interactions in the workplace (Rafaeli \& Sutton, 1987), can differ for males and females. The reported differences in emotional labour levels between the full-time and part-time university lecturers, was not significant.

\subsection{Context of the Study}

It is worth noting that at the time of commencement of the study, organisational and structural changes had just been announced at the UK University in which the study was conducted which may have impacted upon the reported high levels of emotional labour and on identified main themes. A main and recurrent sub-theme identified, in the qualitative thematic analysis (see Table 10 and 11), was uncertainty about the future. Such findings support Tytherleigh, Webb, Cooper, and Ricketts' (2005) argument that job insecurity can be associated with increased stress during organisational change. An additional suggested factor for the high levels of emotional labour reported is the impact of continual and evolving change in the UK higher education sector on university lecturers. Qualitative thematic findings also revealed main themes of eroding job autonomy and increased workloads (see Table 9 and 10) further supporting the impact of change on a university lecturer's job specific role demands. Performing in a role which is compatible with the needs and competence of an individual may lessen the extent to which emotional labour is needed (Grandey, 2003) and thus emotional harmony is promoted (Brennan 2006). Whereas, performing high levels of emotional labour can be associated with 'role incongruence' meaning that an individual is undertaking a job that is not 'best fit' to their authentic self (Parkinson, 1991). The high levels of emotional labour reported by this sample of university lecturers could therefore suggest that they are performing emotional labour to disguise their dissatisfaction with the continual changes to their job role as Ogbonna and Harris (2004) previously found.

High emotional labour usually indicates that a job involves frequent people contact (Mann 1999a; 1999b). The role of a university lecturer is varied (Ogbonna and Harris 2004) and they have multiple stakeholders, including the senior management team, external agencies, research teams, society at large (Ogbonna \& Harris 2004) and a growing population of students (Kinman 2008). Therefore, it is likely that a higher proportion of a university lecturer's time now involves more frequent people contact, particularly in dealing with the increasing demands of students. It could therefore be argued that increased people contact is a factor in high emotional labour, supporting Constanti and Gibbs (2004) findings.

Interestingly, although high levels of emotional labour were reported, qualitative thematic analysis indicated that the sample of university lecturers also felt satisfied in their jobs. This contradicts Rutter and Fielding (1988) who found that emotional labour in the workplace was positively associated with overall stress and negatively associated with job satisfaction. However, job autonomy was also an identified main theme, which may have influenced the levels of 
reported job satisfaction being experienced. This supports Shuler and Sypher (2000) who found a positive association between job autonomy and job satisfaction. High levels of emotional labour are usually associated with low job autonomy and low job dissatisfaction (Wharton, 1993). The seemingly contradictory findings of this study may be explained in terms of Herzberg's (1966) two factor theory. The theory suggests that only job content-related facets lead to satisfaction and job context-related factors can lead to job dissatisfaction. Thus suggesting that for this sample of university lecturers the core job content-related facets of their roles continue to provide job satisfaction even with external influences changing their job specific role demands.

Frequent performance of high levels of emotional labour can negatively impact an employee's wellbeing (Mann 1999b; Mann \& Cowburn, 2005). Therefore, the high levels of emotional labour found in university lecturers may be a cause for concern. A number of public service sector occupations, reporting high levels of emotional labour, have also experienced high levels of turnover and staff shortages (Huxley et al. 2005; Scott, 2002). Research has already indicated that academic roles are becoming more demanding and stressful and UK higher education is becoming a focus for concern and research on occupational stress (Bradley \& Eachus 1995; Kinman 2001). Workplace stress is strongly associated with emotional labour, with the relationship being described as 'cyclical' (Mann, 1999a), and whilst the present study did not record frequency of emotional labour, it has been suggested that it is excessive or high frequency of high levels of emotional labour that is associated with negative effects on health and wellbeing and not the occasional performance of high emotional labour (Mann 1999a; 1999b; Mann \& Cowburn, 2005). Findings do nevertheless support the need for continued investigation into workplace stress and emotional labour in university lecturers.

\subsection{Modelling Emotional Labour in Higher Education}

\begin{tabular}{|llllll|}
\hline \multicolumn{5}{c|}{ 'PESTLE' EXTERNAL FORCES } \\
Political: & Economic: & Social: & Technological: & Legal: & Environmental: \\
- Increased & - Managerilism & - Increasing student & - Electronic revolution & - Increased & - Diverse delivery \\
Commercialisation & - Reduced public-funding & numbers \& demands & & external & \\
- Globalisation & - Mergers \& Restructures & - Society demands & & regulations \\
- Higher participation & - Financial Self-reliance & & & & \\
\hline
\end{tabular}

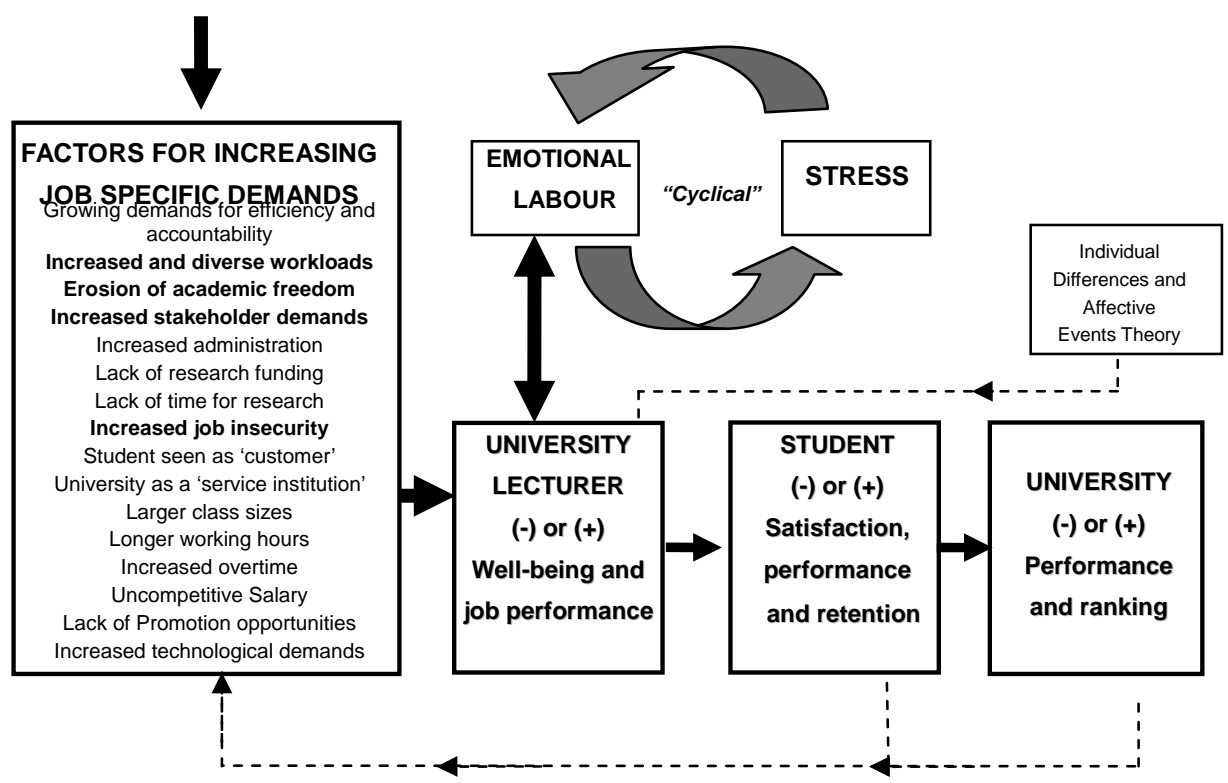

Figure 3: The Higher Education Emotional Labour Model (HEEL Model)

Based on the available research literature and findings reported in the current study, a conceptual model of emotional labour in university lecturers within higher education is proposed (Figure 3). The Higher Education Emotional Labour (HEEL) model conceptualises a cyclical process of possible contributory factors for emotional labour in university lecturers and suggests determining factors for high levels of emotional labour in university lecturers (Constanti \& Gibbs 2004; Ogbonna \& Harris 2004). Political, Economic, Social, Technological, Legal and 
Environmental (PESTLE) forces drive change in UK higher education, directly impacting and changing a university lecturer's job-specific role demands (Kinman, 2008) A university lecturer's job has been associated with occupational stress (Kinman \& Jones 2004; Kinman, 2008) and stress has a cyclical relationship with emotional labour (Hochschild, 1983; Fineman \& Sturdy 1999; Mann 1999a; Rutter \& Fielding 1988). Therefore stress could be suggested as a major contributory factor for emotional labour. The effect of performing emotional labour can have both a functional and dysfunctional impact on a university lecturer's well-being, job satisfaction and job performance. As found by Heskett, Sasser and Schlesinger (1997) in their Service-Profit Chain equation, the relationship between a university lecturer and their customers (students) could be a critical factor in the overall performance of the university. Therefore, a university lecturer's wellbeing, job satisfaction and job performance could be suggested as predicting factors for student satisfaction, student performance and student retention. Student satisfaction, student and university performance (negative or positive) can be further suggested as predictive factors for a university lecturer's level of job satisfaction and emotional labour levels. Therefore, the Higher Education Emotional Labour (HEEL) model could be conceptualised as either a virtuous or vicious circle.

\subsection{Research Implications}

Emotional labour must be recognised by university senior management as a persistent feature of the university lecturer role. This recognition is critical because high emotional labour intensity poses a possible commercial risk. High emotional labour levels can be associated with dysfunctional factors which can be damaging for a university lecturer wellbeing, job satisfaction and job performance, resulting in possible implications for student performance and satisfaction and thus impacting on overall university performance (see Hochschild, 1983; Maslach \& Jackson, 1981; Albrecht \& Zembe, 1985; Welch, 1997; Wharton \& Erickson, 1993; Brotheridge \& Gandey, 2002). Figure 3 helps illustrate the potential impact and interplay between suggested critical factors, the identification of which could be even more crucial in times of increased organisational change.

Particular acknowledgment of the emotional demands faced by newly qualified and less experienced university lecturers is also warranted in terms of staff recruitment, staff retention and staff wellbeing (Scott, 2002; Huxley et al., 2005).

In recognition of the possible commercial risks linked to high levels of emotional labour in university lecturers, and in order to enhance their wellbeing and job performance, it is necessary for university management to design and implement interventions to help university lecturers manage their emotions more effectively. Although opportunities for enhancing job autonomy may be limited, increasing control over the emotional labour process by offering training interventions in the form of - for example-emotional awareness, emotional intelligence training, coping and stress-management techniques and similar, are likely to be beneficial (Mann, 2004).

Continued research is needed to determine, more explicitly, the frequency of emotional labour in university lecturers and also to test the validity of the proposed Higher Education Emotional Labour (HEEL) model. Qualitative semi-structured interviews could also be undertaken with a sample of university lecturers which would enhance and deepen understanding of factors directly affecting performance of emotional labour (Greene 1997). In light of the pace of change in UK higher education, the job characteristics of a university lecturer's role should also be fully explored, examining issues of change and staff and organisation expectations.

\section{Conclusions}

The study presents findings from, what appears to be, the first quantitative study of emotional labour in university lecturers. Findings suggest that university lecturers are performing relatively high levels of emotional labour compared even to other occupations where emotional labour is considered particularly prevalent. High levels of emotional labour found in university lecturers is perhaps one symptom of the transformational change impacting higher education in the UK. The transformational change in higher education over the last quarter-century has been dramatic and there is little sign of the slowing or cessation of change any time soon. Thus, identifying factors relevant to the wellbeing of university lecturers and which may impact, either directly or indirectly, on the performance of higher education institutions seems a very worthy area of for continued investigation. The study describes a conceptual model of emotional labour in higher education, the Higher Education Emotional Labour model, that attempts to conceptualise relevant contributory factors for emotional labour in university lecturers in order to enhance understanding of the emotional labour relationships in higher education and to provide impetus further research. The model illustrates the implications of the increased job-specific role demands, suggested as predictive factors for 'high' emotional labour in university lecturers, and highlights the critical question of whether 
the traditional role of a university lecturer still fits within new and continually evolving higher education frameworks and associated cultures.

Whilst this study constitutes an important first step in mixed-methodological investigation of emotional labour in university lecturers, clearly further research is necessary to determine the frequency and intensity of emotional labour and to explore in more depth the potential predictors and key variables identified. As the pace of change continues to accelerate in higher education, it is paramount that university senior management recognise the implications of these external macro level changes, and how these changes influence the emotional challenges they bring for university lecturers.

\section{References}

Albrecht, K., \& Zemke, R. (1985). Service America! Doing business in the new economy. Homewood, IL: Dow Jones-Irwin.

Ashforth, B., \& Humphrey, R. (1993). Emotional Labor in Service Roles: The influence of Identity. Academy of Management Review, 18(1), 86-115.

Ashforth, B., \& Humphrey, R. (1995). Emotions in the Workplace: A Reappraisal. Human Relations, 48(2), 99-125. http://dx.doi.org/10.1177/001872679504800201

Asthana, A. (2008, 25 May). Lecturers' workloads cuts teaching time. The Observer. Retrieved from www.guardian.co.uk/education/2008/may/25/highereducation.students

Bolton, S.C. (2001). Changing faces: nurses as emotional jugglers. Sociology of Health and Illness, 23, 85-100. http://dx.doi.org/10.1111/1467-9566.00242

Bradley, J., \& Eachus, P. (1995). Occupational Stress Within a U.K. Higher Education Institution. International Journal of Stress Management, 2(3), 145-158. http://dx.doi.org/10.1007/BF01740300

Braun, V., \& Clarke, V. (2006). Using thematic analysis in psychology. Qualitative Research in Psychology, 3, 77-101. http://dx.doi.org/10.1191/1478088706qp063oa

Brennan, K. (2006). The Managed Teacher: Emotional Labour, Education, and Technology. Educational Insights, 10(2), 55-65.

Brotheridge, C. M., \& Grandey, A. A. (2002). Emotional labor and burnout: Comparing two perspectives of 'people work'. Journal of Vocational Behavior, 60, 17-39. http://dx.doi.org/10.1006/jvbe.2001.1815

Cohen, J. (1988). Statistical Power Analysis for the Behavioral Sciences (2nd edition.). Hillsdale NJ: Lawrence Erlbaum Associates.

Constanti, P., \& Gibbs, P. (2004). Higher education teachers and emotional labour. International Journal of Educational Management, 18(4), 243-249. http://dx.doi.org/10.1108/09513540410538822

Court, S. (1999). Autonomy eroded by the long arm of the state. Times Higher Education. Retrieved from www.timeshighereducation.co.uk/story.asp?storyCode $=146577 \&$ sectioncode $=26$

DfES. (2005). Participation Rates in Higher Education: Academic Years 1999-2000 - 2003/04, Department for Education and skills, National Statistics. Retrieved from www.dcsf.gov.uk/rsgateway/DB/SFR/s000572/SFR14-2005v3.pdf

Erickson, R.J., \& Grove, W.J.C. (2007). Why Emotions Matter: Age, Agitation, and Burnout Among Registered Nurses. Online Journal of Issues in Nursing, 13(1). Retrieved from www.nursingworld.org/MainMenuCategories/ANAMarketplace/ANAPeriodicals/OJ

Erickson, R.J., \& Ritter, C. (2001). Emotional labor, burnout, and in-authenticity: Does gender matter? Social Psychology Quarterly, 64(2), 146-163. http://dx.doi.org/10.2307/3090130

Fineman, S., \& Sturdy, A. (1999). The emotions of control: A qualitative exploration of environment regulation. Human Relations, 52(5), 631-663. http://dx.doi.org/10.1177/001872679905200504

Goffman, E. (1959). The Presentation of Self in Everyday Life. New York: Doubleday.

Grandey, A.A. (2003). When "the show must go on": Surface acting and deep acting as determinants of emotional exhaustion and peer-rated service delivery. Academy of Management Journal, 46(1), 86-96. http://dx.doi.org/10.2307/30040678 
Greene, J.C., \& Caracelli, V.J. (1997). Defining and describing the paradigm issue in mixed-method evaluation. In J. C. Greene and V. J. Caracelli (eds). Advances in mixed-method evaluation: The challenges and benefits of integrating diverse paradigms. New Directions for Program Evaluation, No.74. San Francisco, CA: Jossey-Bass, 5-18.

Hargreaves, A. (1998). The emotional politics of teaching. Teacher and Teacher Education, 14(8), 835-854. http://dx.doi.org/10.1016/S0742-051X(98)00025-0

Hargreaves, A. (2000). Mixed emotions: teachers' perceptions of their interactions with students. Teaching and Teacher Education, 16, 811-826. http://dx.doi.org/10.1016/S0742-051X(00)00028-7

Health and Safety Executive. (2008). Psychosocial Working Conditions in Britain. HSE. Retrieved from http://www.hse.gov.uk

Herzberg, F. (1966). Work and the Nature of Man. Cleveland: World Publishing.

Heskett, J.L., Sasser, W.E., \& Schlesinger, L. (1997). The Service Profit Chain. New York: Free Press.

Hochschild, A.R. (1983). The Managed Heart: Commercialization of Human Feeling. London: University of California Press.

Humpel, N., \& Caputi, P. (2001). Exploring the relationship between work stress, years of experience and emotional competency using a sample of Australian mental health nurses. Journal of Psychiatric and Mental Health Nursing, 8(5), 399-403. http://dx.doi.org/10.1046/j.1365-2850.2001.00409.x

Huxley, P., Evans, S., Gately, C., Webber, M., Mears, A., Pajak, S., Kendall, T., Medina, J., \& Katona, C. (2005). Stress and pressures in mental health social work: The worker speaks. British Journal of Social Work, 35, 1063-1079. http://dx.doi.org/10.1093/bjsw/bch218

Kinman, G. (2001). Pressure points: A review of stressors and strains in UK academics. Educational Psychology, 21(4), 473-492. http://dx.doi.org/10.1080/01443410120090849

Kinman, G. (2008). Work stressors, health and sense of coherence in UK academic employees. Educational Psychology, 28(7), 823-835. http://dx.doi.org/10.1080/01443410802366298

Kinman, G., \& Jones, F. (2004). Working to the Limit. London: AUT.

Lashley, C. (2002). Emotional harmony, dissonance and deviance at work. International Journal of Contemporary Hospitality Management, 14(5), 255-257. http://dx.doi.org/10.1108/09596110210433808

Lewis, P., \& Simpson, R. (2007). Gendering Emotions in Organizations. New York: Palgrave Macmillan

Mann, S. (1997). Emotional labour in organizations. Leadership \& Organisation Development Journal, 18, 4-12. http://dx.doi.org/10.1108/01437739710156231

Mann, S. (1999a). Emotion at Work: To What Extent are We Expressing, Suppressing, or Faking It? European Journal of Work and Organisational Psychology, 8(3), 347-369. http://dx.doi.org/10.1080/135943299398221

Mann, S. (1999b). Hiding what we feel, faking what we don't. London: Vega.

Mann, S. (2004). People-work': emotion management, stress and coping. British Journal of Guidance \& Counselling, 32(2), 205-221. http://dx.doi.org/10.1080/0369880410001692247

Mann, S., \& Cowburn, J. (2005). Emotional labour and stress within mental health nursing. Journal of Psychiatric and Mental Health Nursing, 12, 154-162. http://dx.doi.org/10.1111/j.1365-2850.2004.00807.x

Maslach, C., \& Jackson, S.E. (1981). The measurement of experiences burnout. Journal of Occupational Behaviour, 2, 99-113. http://dx.doi.org/10.1002/job.4030020205

Meier, K.J., Mastracci, S.H., \& Wilson, K. (2006). Gender and Emotional Labor in Public Organizations: An Empirical Examination of the Link to Performance. Published Administration Review, 66(6), 899-909. http://dx.doi.org/10.1111/j.1540-6210.2006.00657.x

Morris, J.A., \& Feldman, D.C. (1996). The dimensions, antecedents and consequences of emotional labor. Academy of Management Review, 1(4), 989-1010.

Naidoo, R. (2008). Building or Eroding Intellectual Capital? Student Consumerism as a Cultural Force in the Context of Knowledge Economy. In Cultural Perspectives on Higher Education, Valimaa, J., \& Ylijoki, O-H (Eds.). London: Springer Netherlands. http://dx.doi.org/10.1007/978-1-4020-6604-7_4 
Ogbonna, E., \& Harris, L.C. (2004). Work Intensification and Emotional Labour among UK university lecturers: An exploratory study. Organisation Studies, 25(7), 1185-1203. http://dx.doi.org/10.1177/0170840604046315

Parkinson, B. (1991). Emotional stylists: Strategies of expression management among Trainee Hairdressers. Cognition and Emotion, 5(5-6), 419-434. http://dx.doi.org/10.1080/02699939108411051

Pierce, J.L. (1995). Gender Trials: Emotional Lives in Contemporary Law Firms. Berkley: California Press.

Rafaeli, A., \& Sutton, R.I. (1987). Expression of emotion as part of the work role. Academy of Management Review, 12, 23-37.

Ritzer, G. (1996). The McDonaldization of Society. Thousand Oaks, CA: Pine Forge.

Rutter, D.R., \& Fielding, P.J. (1988). Sources of occupational stress: an examination of British police officers. Work and Stress, 2, 291-299. http://dx.doi.org/10.1080/02678378808257490

Scott, H. (2002). Nursing profession is finding it harder to retain nurses. British Journal of Nursing, 11, 1052.

Sharma, U., \& Black, P. (2001). Look good, feel better: beauty therapy as emotional labour. Sociology, 35(4), 913-931.

Shuler, S., \& Sypher, B.D. (2000). Seeking emotional labor: When managing the heart enhances the work experience. Management Communication Quarterly, 14(1), 50-89. http://dx.doi.org/10.1177/0893318900141003

Spratt, C., Walker, R., \& Robinson, B. (2004). Mixed research methods: Practitioner Research and Evaluation Skills Training. Open and Distance Learning.

Stenross, B., \& Kleinman, S. (1989). The highs and lows of emotional labor: Detectives' encounters with criminals and victims. Journal of Contemporary Ethnography, 17, 435-452. http://dx.doi.org/10.1177/089124189017004003

Sutton, R.J. (1991). Maintaining norms about expressed emotions: The case of bill collectors. Administrative Science Quarterly, 36, 245-268. http://dx.doi.org/10.2307/2393355

Tytherleigh, M., Webb, C., Cooper, C., \& Ricketts, C. (2005). Occupational stress in UK higher education institutions: A comparative study of all staff categories. Higher Education Research and Development, 24(1), 41-61. http://dx.doi.org/10.1080/0729436052000318569

UCU (2008a, 27 May). University and College Union, Rising class sizes but more time spent on Admin than students or research - life as $21^{\text {st }}$ century lecturer. Retrieved from www.ucu.org.uk

UCU (2008b, 11 December). University and College Union. Stress levels in higher education way above recommended levels. Retrieved from www.ucu.org.uk

Welch, J. (1997). Forced smiles gloss over hidden trauma: employees who fake their Emotions. People Management, $3,15$.

Wharton, A. (1993). The effective consequences of service work; managing emotions on the job. Work and Occupations, 20(2), 205-32. http://dx.doi.org/10.1177/0730888493020002004

Wharton, A.S., \& Erickson, R.J. (1993). Managing emotion on the job and at home: Understanding the consequence of multiple emotional roles. Academy of Management Review, 18(3), 457-486.

Willmott, H. (1995). Managing the academics: commodification and control in the development of university education in the UK. Human Relations, 4(9), 993-1114. http://dx.doi.org/10.1177/001872679504800902

Ybema, J., \& Smulders, P. (2002). Emotional demand and the need to hide emotions at work. Behavior \& Organization, 26(3), 129-146. 